Lilianna Miodońska

\title{
Republika Serbii w NATO? Poszukiwanie nowych koncepcji bezpieczeństwa
}

\section{Szczyt w Lizbonie i jego znaczenie dla stosunków NATO-Serbia}

Podczas odbytego w dniach 19-20 listopada 2010 r. szczytu NATO w Lizbonie została opracowana nowa koncepcja strategiczna Sojuszu. Była to pierwsza od 1999 r. całościowa doktryna strategiczna Paktu, stwierdzająca, że zagrożenie atakiem konwencjonalnym przeciw terytorium NATO jest niskie, natomiast wiele regionów $i$ państw na świecie doświadcza nabywania znaczacych, nowoczesnych zdolności militarnych z konsekwencjami dla stabilności międzynarodowej $i$ bezpieczeństwa euroatlantyckiego, które trudno jest przewidzieć; obejmuje to proliferacje rakiet balistycznych, które stanowiq realne $i$ rosnace zagrożenie dla obszaru euroatlantyckiego. Jako poważne zagrożenia dla NATO wymieniono także: proliferację broni jądrowej i innej broni masowej zagłady; terroryzm, zwłaszcza wspomagany nowoczesna technologia; niestabilność i konflikty poza granicami NATO, mogące sprzyjać ekstremizmowi, terroryzmowi i transgranicznemu przemytowi broni, narkotyków i ludzi; coraz częstsze, lepiej zorganizowane i przynoszace coraz większe straty cyberataki. Objętościowo największą część nowej koncepcji zajmuja jednak zarządzanie kryzysowe i działania prewencyjne: kontrola 
zbrojeń, rozbrojenie i nieproliferacja oraz współpraca (partnerstwo) na rzecz umacniania bezpieczeństwa z państwami spoza Sojuszu (w pierwszym rzędzie z Rosja) i organizacjami międzynarodowymi, przy utrzymaniu zasady tzw. otwartych drzwi (możliwości przyjęcia do NATO kolejnych państw europejskich spełniających standardy demokratyczne) $)^{1}$.

Nowa koncepcja zakłada zapewnienie bardziej aktywnego i głębszego zaangażowania w sprawy bezpieczeństwa światowego, czemu służyć mają m.in. istniejące już partnerstwa z krajami spoza Sojuszu oraz organizacjami międzynarodowymi. Położenie akcentu na ten aspekt przyszłej strategii NATO daje możliwość budowy relacji z takimi krajami, jak Serbia. Partnerstwa dotycza nie tylko bezpieczeństwa euroatlantyckiego, ale również międzynarodowego. Sprzyjają zapewnieniu stabilizacji i wzmacniają wspólne wartości. Umożliwiają wzajemną wymianę doświadczeń, dają poparcie przeprowadzanym reformom, oferuja partnerska pomoc w przygotowaniu poszczególnych krajów do przyszłego włączenia się w struktury Sojuszu. W związku z tym w Lizbonie został położony nacisk na wzmocnienie działalności Partnerstwa dla Pokoju (PdP) oraz Rady Partnerstwa Euroatlantyckiego jako struktur wyznaczających podstawowy zakres dialogu i praktycznej współpracy pomiędzy stowarzyszonymi krajami, których Serbia jest aktywnym członkiem.

Dla bezpieczeństwa euroatlantyckiego zachodnie Bałkany oraz Serbia maja kluczowe znaczenie. Większość krajów tego regionu należy do Paktu Północnoatlantyckiego lub wyraziła chęć akcesu. Spośród nich Albania, Chorwacja i Słowenia sa już członkami Sojuszu. Serbia jest uczestnikiem

${ }^{1}$ Zob. A. Wilk, NATO po szczycie w Lizbonie - konsekwencje dla Europy Środkowej $i$ Wschodniej, „Tydzień na Wschodzie” 2010, nr 39 (157), http://www.osw.waw.pl/pl/publikacje/tydzien-na-wschodzie (dostęp 24 XI 2010). 
Partnerstwa dla Pokoju. Republika Macedonii od 1999 r. właczyła się w realizację Planu Działania na rzecz Członkostwa (MAP), jednak jej ewentualne członkostwo w Sojuszu jest blokowane przez Grecję, domagająca się zmiany nazwy państwa. W związku z tym, że Macedończycy, mimo chęci wstapienia do NATO, nie sa gotowi ulec greckim naciskom, rozwiązanie „problemu nazwy” nie wydaje się możliwe, a przynajmniej bliskie.

Spośród państw byłej Jugosławii do członkostwa w MAP została również zaproszona Czarnogóra, a realizacja planu wobec Bośni i Hercegowiny zależy np. od przebiegu procesu rejestracji mienia wojskowego, do czego państwo to zostało zobligowane.

W stosunku do Serbii NATO stara się pogłębiać stosunki bilateralne. W ostatnich latach skupiono się głównie na zagadnieniach reformy systemu obrony oraz planowania w przypadku sytuacji nadzwyczajnych. W ramach PdP współpraca koncentruje się na zacieśnianiu wojskowej interoperacyjności sił zbrojnych Serbii z państwami-członkami NATO - w celu współdziałania podczas operacji dla pokoju. Chodzi tu o wkład Serbii zarówno w akcje Sojuszu, jak i w operacje międzynarodowe pod auspicjami Narodów Zjednoczonych lub Unii Europejskiej (UE). We wszystkich udział tego kraju będzie mile widziany.

Już w kwietniu 2009 r. Serbia i Sojusz uzgodniły pierwszą transzę 19 partnerskich celów, a w maju 2010 r. ich wykaz został znacznie poszerzony. Obaj partnerzy założyli Grupę ds. Reformy Obrony NATO-Serbia, mająca na celu pomoc $\mathrm{w}$ reformowaniu systemu obrony i w realizacji postawionych sobie zadań ${ }^{2}$.

${ }^{2}$ Zob. L. Rossin, Nova Srbija, novi NATO - Vizija budućnosti za 21. vek, [w:] Nova Srbija, novi NATO - vizija budućnosti za XXI vek. Zbornik tekstova, Beograd 2011, s. 19. 
Jakie ostatecznie stanowisko wobec Sojuszu Północnoatlantyckiego zajmie bałkański partner - trudno przewidzieć. Liderzy NATO pozostawili Serbii decyzję w kwestii rozwoju wzajemnych stosunków i ich ewentualnego tempa. Ambasador Lawrance Rossin nakreślił kilka możliwych w przyszłości rozwiązań:

1) Jeśli Serbia zdecyduje, że jej przyszłość leży w dalszym pogłębianiu partnerstwa $z$ NATO, znajdzie gotowego partnera pomiędzy naszymi 28 członkami.

2) Jeśli nie chce pogtębić partnerstwa, będzie to również do zaakceptowania dla NATO, chociaż bylibyśmy rozczarowani strata wzajemnych możliwości.

3) Jeśli Serbia zdecyduje, i̇e pragnie członkostwa w NATO, podobnie jak jej sqsiedzi, znajdzie otwarte drzwi Planu Dziatania na rzecz Członkostwa.

4) Jeśli Serbia zdecyduje, że nie chce wejść do NATO, będzie to również $w$ porzqdku, gdyż od nikogo nie wymaga sie zostania członkiem NATO, ani też nie sq uzależnione od tego nasze dobre stosunki. NATO $i$ narody $w$ jego sktadzie maja bardzo bliska i ptodna interakcje $z$ wszystkimi krajami Europy, które z obojętnie jakiego powodu nie przytaczyty się do NATO, Partnerstwa dla Pokoju, a szczególnie misji. Tak będzie również w przypadku Serbii poza NATO, jeśli to będzie przez was wybrany kierunek ${ }^{3}$.

\section{Przeszkody na drodze ewentualnego włączenia się Serbii w struktury NATO}

Biorąc pod uwagę rozmieszczenie krajów-członków Paktu Północnoatlantyckiego na mapie Europy, Republika Serbii jest wśród nich niemal samotną wyspą. Kraj ten ciągle stoi

${ }^{3}$ Ibidem, s. 19-20. 
wobec dylematu: „za” czy „przeciw” przyłączeniu się do NATO. Trudno się temu dziwić, biorąc pod uwagę jeszcze bardzo świeże w pamięci narodu serbskiego wydarzenia z 1999 r., kiedy wojska Sojuszu dokonały agresji na niezawisłe państwo, jakim była Związkowa Republika Jugosławii (SRJ). Jedenastotygodniowe naloty zostały nazwane przez administrację ówczesnego prezydenta USA, Billa Clintona, humanitarna wojna, która do tej pory nie znajdowała uzasadnienia w istniejącym międzynarodowym prawie. Miała być prowadzona w obronie praw człowieka, a działania zbrojne zostały podjęte w celu przywrócenia pokoju.

NATO, wraz ze swymi sojusznikami, starało się wszelkimi siłami uzasadnić podjęte kroki... i znalazło poparcie dla swych agresywnych poczynań. Oto cytowana wielokrotnie wypowiedź ówczesnego prezydenta Republiki Czeskiej, Vaclava Havla: To jest prawdopodobnie pierwsza wojna, która nie byta prowadzona $w$ imie "narodowego interesu”, ale w imie zasad i wartości. Jeśli o którejkolwiek $z$ wojen można powiedzieć, że jest etyczna lub $\dot{z} e$ jest prowadzona $z$ moralnych powodów, to właśnie ta wojna [...]. Zwiazkowa Republikę Jugosławii NATO zaatakowało bez bezpośredniego mandatu ONZ. To nie byt nieodpowiedzialny akt agresji, ani nie stanowi złamania międzynarodowego prawa ${ }^{4}$. W podobnym tonie wypowiadał się angielski premier, Tony Blair: To jest sprawiedliwa wojna, która nie bazuje na roszczeniach terytorialnych, ale na wartościach ${ }^{5}$.

W ciagu 78 dni, rzekomo „chirurgicznie precyzyjnych” nalotów, trzy spośród pięciu zbombardowanych celów było obiektami cywilnymi, co ostatecznie doprowadziło do ogromnych

${ }^{4}$ M. Pečuljić, Globalizacija. Dva lika sveta, Beograd 2005, s. 150-151.

${ }^{5}$ Cyt. za: N. Chomsky, Američki mač sa dve oštrice. Boston Globe, 05.07.1999, http://news.beograd.com/srpski/clanci_i_misljenja/990705_americki_mac_sa_dve_ostrice.html (dostęp 20 IX 2009). 
zniszczeń w gospodarce jugosłowiańskiej, w której odnotowano spadek produktu narodowego rzędu $40 \%$, a spadek produkcji przemysłowej o $44 \%{ }^{6}$. Natomiast tzw. kolateralne szkody, jak nazwał je eufemistycznie rzecznik prasowy Sojuszu Jamie Shea, wyniosły około 2 tys. cywilnych mieszkańców Serbii ${ }^{7}$.

Do tej pory głównym celem Paktu Północnoatlantyckiego była ochrona wolności i zapewnienie stabilności oraz dobrobytu państw w nim zrzeszonych. Sojusz wyznaczał sobie zadania polityczne oraz militarne, związane $\mathrm{z}$ dążeniem do pokoju i bezpieczeństwa. Kraje skupione w ramach NATO zobowiazywały się do wzajemnego udzielenia pomocy i wsparcia w sytuacjach zagrożenia militarnego. Strategiczna koncepcja Sojuszu z 1991 r. zakładała, że ma on charakter defensywny, a żaden rodzaj sił zbrojnych nie zostanie wykorzystany poza koniecznością samoobrony. Dokumentem zaś z 1999 r., napisanym w trakcie powietrznej kampanii wojsk sojuszniczych na Serbię, stworzono precedens, dotyczący poszerzenia możliwości reagowania wojsk NATO, wykraczajacy poza definicję samoobrony, uzasadniający humanitarne interwencje $\mathrm{w}$ celu zapobiegania konfliktom.

Secesja Kosowa i uznanie przez większość państw członkowskich NATO niezawisłości tej byłej prowincji SRJ również nie przysporzyło Paktowi popularności. Wielokrotnie jednak podkreślano, że w skład Sojuszu wchodzą zarówno kraje, które uznały niezawisłość Republiki Kosowa, jak i te, które jej

${ }^{6}$ Međunarodno javno pravo: zbirka dokumenata, prir. V. Hadži-Vidanović, M. Milanović, Beograd 2005, s. 239, cyt. za: M. Radojičić, „Rat na granici prava i morala"? Agresija NATO-a na SRJ u međunarodno-etičkoj perspektivi, „Filozofija i društvo” [Beograd] 2011, vol. 22, br. 3, s. 143.

${ }^{7}$ E. Pieciul-Karmińska, Językowe nadużycia. Stowa jak arszenik, „Polityka", 19 IV 2007, http://www.polityka.pl/spoleczenstwo/niezbednikinteligenta/216106,1,jezykowe-naduzycia.read\#ixzz21e9foIEK (dostęp 19 IV 2007). 
tego statusu odmówiły, a NATO - z uwagi na swój charakter - nie mogło zajać żadnego stanowiska w kwestii prawnego statusu nowo powstałego państwa.

Jednak problem Kosowa pozostaje dla Republiki Serbii ciagle nierozwiązana kwestia, a jej stanowisko wspiera Rosja. Moskwa od samego początku krytykowała państwa Zachodu, które uznały niepodległość prowincji, podkreślając, że proklamowanie jej niezawisłości było nielegalne i stanowiło niebezpieczny precedens, zagrażający międzynarodowej stabilności i rażąco naruszający prawo międzynarodowe.

Dla Serbii dyplomatyczne wsparcie jej tradycyjnego i potężnego sojusznika ma ogromne znaczenie w związku z sytuacją wewnętrzna państwa. Belgrad obawia się możliwości dalszej, trwającej już od ponad 20 lat, dezintegracji swego terytorium. Groźba ta jest całkowicie realna. Należy podkreślić, że Serbia jest jedynym krajem bałkańskim o takim zróżnicowaniu etnicznym, co skutkuje jej największą wielokulturowością. Znaczną część społeczeństwa stanowią muzułmanie. Wielu z nich łączą bliskie więzi zarówno rodzinne, religijne, jak i polityczne z Boszniakami w sasiedniej Bośni i Hercegowinie. Muzułmanie podkreślają swoja odrębność narodową w Serbii, dążąc od 1991 r. do secesji jej południowego regionu - Sandżaku (Raška). Uosobieniem tych starań jest sandżacki główny mufti - Muamer Zukorlić. Sytuacja staje się groźna, gdyż w wyniku pierwszych bezpośrednich wyborów, przeprowadzonych w 2010 r., wspólnota kulturowa z Zukorliciem na czele, mimo braku większości, ogłosiła zwycięstwo i ukonstytuowała Boszniacką Radę Narodową (Bošnjačko nacionalno vjeće, BNV). Organ ten przyjął deklarację, mocą której naród boszniacki został proklamowany konstytutywnym narodem Serbii. Po zwycięstwie w wyborach do rad narodowych Zukorlić 
zadeklarował, że terytorium Sandżaku jest wolne i nigdy nie zostanie zniewolone ${ }^{8}$.

Podobne dążenia separatystyczne obserwuje się również w Wojwodinie, która od dawna miała status okręgu autonomicznego, podobnie jak Kosowo.

W stosunkach pomiędzy obydwoma państwami istotną rolę odgrywają także problemy gospodarcze, rzutujące na ewentualną decyzję Serbii o akcesie do Paktu Północnoatlantyckiego. Chodzi tym razem o energetyczną strategię Rosji wobec Republiki Serbii. Naftowy gigant, jakim jest Rosja, to właściciel dwóch serbskich kompanii naftowych - Beopetrolu i Jugopetrolu, co daje mu faktycznie pełną kontrolę rynku energetycznego w tym kraju. Ponadto Rosja planowała na Bałkanach ogromną inwestycję, którą miała być południowa nitka (Južni tok) gazociagu biegnącego przez Serbię, z odgałęzieniem poprzez Republikę Serbską do Federacji Bośni i Hercegowiny. Z uwagi na to, że rosyjski surowiec pokrywa europejskie zapotrzebowanie w $23-40 \%$, znaczenie strategiczne tej inwestycji byłoby ogromne. Gazociag miał biec przez Morze Czarne do Bułgarii, gdzie miał rozgałęzić się na odnogę łączącą Serbię, Chorwację, Słowenię, Węgry i Austrię, i druga, która, według planów, miała prowadzić przez Grecję do Włoch. Jak zauważył Aleksandar Fatić: W świetle projektu Potudniowa Nitka znaczace jest istnienie nieoficjalnego dokumentu rosyjskiego Ministerstwa Spraw Zagranicznych, noszqcego nazwe „Program skutecznego wykorzystania polityki zagranicznej $w$ dtugoplanowym rozwoju Rosji”, opublikowanego w 2010 r. przez rosyjskie wydanie czasopisma „Newsweek” oraz chorwacki „Jutarnji list". Dokument ten przedstawia plan budowy rurociagu

${ }^{8}$ Muamer Zukorlić, http://sr.wikipedia.org/sr-el/\%D0\%9C\%D1\%83\%D1\% 84\%D1\%82\%D0\%B8\%D1\%98\%D0\%B0_\%D0\%9C\%D1\%83\%D0\%B0\%D0\%BC\%D0\%B5\%D1\%80_\%D0\%97\%D1\%83\%D0\%BA\%D0\%BE\%D1\%80\%D0\%BB\%D0\%B8\%D1\%9B (dostęp 4 XI 2012). 
naftowego, nazwanego „Przyjaźn Adria”, dtugości $3200 \mathrm{~km}$, mogacego pompować rocznie od 5 do $15 \mathrm{mln}$ ton ropy $w$ trakcie trzech faz jego stopniowej aktywacji. Rurociag rozpoczynałby się $w$ rosyjskim mieście Samara i prowadzitby poprzez Biatoruś, Ukrainę, Stowacje i Węry do Omiša na chorwackiej wyspie Krk. Budowa Potudniowej Nitki, Przyjaźn Adria i kraje czlonkowskie NATO $w$ regionie zostatyby wtaczone $w$ rosyjski projekt gazowy i popadtyby w rosyjska gazowa zależność ${ }^{9}$.

Biorąc powyższe pod uwagę, Republika Serbii stoi wobec dylematu wyboru, który jest wyjątkowo skomplikowany i musi przebiegać wielopłaszczyznowo. Wymaga bowiem ustosunkowania się do żywotnych problemów, z którymi boryka się państwo na skutek swego położenia geopolitycznego, skutków agresji NATO, a także wcześniejszej polityki państw ościennych, skazującej Serbię na długotrwałe embargo, restrykcje ekonomiczne oraz izolację na arenie międzynarodowej. Dodatkowo utrudnia sytuację wpływ opinii publicznej, zdecydowanie podzielonej pomiędzy zwolenników Serbii autorytarnej, optującej za zachowaniem państwa nawet za cenę dyktatury, popierającej rządy byłego przywódcy - Slobodana Miloševicia - oraz demokratycznej i europejskiej, biorącej pod uwagę włączenie kraju w struktury NATO.

\section{W NATO czy poza Sojuszem?}

Analizujac serbską historię od momentu rozpadu federacyjnego państwa, widać, że sporo miejsca w niej zajmują również relacje z Sojuszem Północnoatlantyckim. W rok

${ }^{9}$ A. Fatić, Srpska strateška dilema između NATO-a i Rusije, [w:] Nova Srbija, novi..., s. 43-44; zob. też K. Žabec, Tajni naputak Rusa: Morate biti u projektu Družba Adria, „Jutarnji list”, 18 V 2010. 
po wojennych doświadczeniach, w kraju doszło do radykalnych przemian politycznych. Zwyciężyła demokracja, a okres od 5 października 2000 r. do 3 marca 2004 r., kiedy na czele państwa stał dr Vojislav Koštunica, zyskał określenie Epoki Peryklesa w nowoczesnej Serbii ${ }^{10}$.

Już wtedy rząd współpracował z NATO w zakresie zapobiegania niepokojom i w rozwiązywaniu kryzysu na południu Serbii, a w marcu 2003 r. w uniemożliwieniu dalszego pogromu Serbów w Kosowie ${ }^{11}$. Równocześnie zostały podjęte kroki w kierunku przyszłej integracji również z Paktem Północnoatlantyckim. Tak więc na przestrzeni bardzo krótkiego okresu została pokonana droga od konfrontacji do współpracy, zakończona konkretnymi decyzjami. W kwietniu 2002 r. Najwyższa Rada Obrony z jej przewodniczącym, V. Koštunica, skierowała do rzadu polecenie, dotyczące rozpoczęcia procesu włączania się do programu PdP. Do końca 2003 r. zostały unormowane stosunki z NATO, a z ponad 20 krajami Serbia zawarła porozumienia o współpracy bilateralnej. Jak stwierdził Milan Karagaća: Do połowy 2004 r. około 800 żotnierzy i osób cywilnych, należacych do systemu obrony, zostato objętych różnorodnymi programami szkolenia, kursami, biorac udziat $w$ seminariach, konferencjach $i w$ innych formach wspótpracy poza granicami kraju. Ponad 200 oficerów uzyskato znajomość języków obcych (angielskiego, francuskiego, wtoskiego i greckiego), dostosowanych do standardów NATO. Koszty, wynoszace ponad $2 \mathrm{mln}$ euro, ponosiły w największym stopniu kraje członkowskie NATO, ale

${ }^{10}$ Petooktobarske promene - Periklovo doba moderne Srbije, 5 X 2012, http://www.rtv.rs/sr_lat/politika/petooktobarske-promene-periklovo-doba-moderne-srbije_276886.html (dostęp 5 X 2012).

${ }^{11}$ Srpsko-albanski sukob, http://sh.wikipedia.org/wiki/Srpsko-albanski_sukob (dostęp 30 X 2012). 
równiė̇ państwa, m.in. Szwajcaria ${ }^{12}$. Efektem pomyślnie rozwijającej się współpracy było przyjęcie Serbii do Partnerstwa dla Pokoju, nawet bez wspominania o konieczności ujęcia gen. Ratko Mladicia jako wypełnienia warunku wstępnego, co wydawało się początkowo przeszkodą nie do pokonania ${ }^{13}$.

Jednak tak obiecująco zapowiadający się rozwój wzajemnych kontaktów został zahamowany już w 2007 r. Zapoczątkował on proces konfrontacji z Paktem Północnoatlantyckim oraz UE, którego przyczyna były niepomyślne negocjacje, dotyczace rozwiąania kwestii Kosowa. Od tamtej pory Serbia nieustannie poszukuje najbardziej odpowiadajacej jej formuły bezpieczeństwa w XXI w. i rozważa jej różnorodne opcje.

Wymienia się tutaj kilka możliwości: 1) neutralność i niezaangażowanie; 2) partnerstwo w zakresie zapewnienia bezpieczeństwa; 3) kolektywne bezpieczeństwo w ramach Organizacji Narodów Zjednoczonych; 4) współpracę zapewniającą bezpieczeństwo w ramach Organizacji Bezpieczeństwa i Współpracy w Europie (OBWE); 5) koalicje zakładane ad hoc; 6) solidarność w ramach Unii Europejskiej; 7) wspólne programy bezpieczeństwa i partnerstwa w ramach NATO ${ }^{14}$.

Najwięcej kontrowersji wywołuje kwestia neutralności państwa. Parlament Zgromadzenia Narodowego Serbii 26 grudnia 2007 r. uchwalił deklarację dotyczącą neutralności kraju. Głosiła ona: W zwiazku z całoksztattem roli NATO, od bezprawnego bombardowania Serbii w 1999 r., bez decyzji Rady Bezpieczeństwa, do Aneksu 11 odrzuconego planu Ahtisaariego, w którym określa się, że NATO jest ostatecznym organem władzy w niezależnym Kosowie, Narodowy Parlament

${ }^{12}$ M. Karagaća, Budući bezbednosni koncept Srbije, [w:] Nova Srbija, novi..., s. 153.

${ }^{13}$ Ibidem .

${ }^{14}$ Zob. ibidem, s. 149. 
Republiki Serbii podejmuje decyzję o wojskowej neutralności Republiki Serbii w stosunku do istniejacych sojuszów wojskowych do ewentualnego rozpisania referendum, które ostatecznie o niej zdecyduje ${ }^{15}$. Deklaracja ta ciagle pozostaje w mocy, ale zdania na jej temat dzielą samych polityków i serbską opinię publiczna.

Konieczność zachowania neutralności jest najczęściej motywowana geopolitycznym położeniem Serbii - jej usytuowaniem na wyjątkowo ważnym obszarze Europy Południowo-Wschodniej, w strefie rozlicznych strategicznych interesów oraz tym, że naród serbski poniósł największe straty w ciagu burzliwego XX w.

Neutralność Serbii w świecie nie została uznana i nic na to nie wskazuje, że taki status ma jej być przyznany. Przy tej okazji podkreśla się, że kraj ten nie posiada stabilnej sytuacji wewnętrznej gwarantującej bezpieczeństwo, a także odpowiednio rozwiniętej gospodarki i stabilnej ekonomii, pozwalającej na rozwijanie autonomicznych środków obrony. Podsumowując, Serbii nie stać na neutralność, która wymagałaby od niej znacznie większych nakładów na obronność, co mogłoby stanowić dla niej gwarancję bezpieczeństwa. Ponadto podkreśla się kwestię modernizacji armii, co może umożliwić jedynie przyłączenie się do Sojuszu. Jako przykład podaje się Chorwację, która otrzymała środki na rozwój własnego przemysłu zbrojeniowego, co pozwala jej na rozwój produkcji celowej, zgodnie ze standardami NATO. Nieprzystapienie Serbii do Paktu będzie równoznaczne m.in. z zahamowaniem jej rozwoju technologicznego ${ }^{16}$.

${ }^{15}$ Cyt. za: ibidem, s. 155.

${ }^{16}$ Programi/Most. Srbija u NATO paktu - za i protiv, http://www.slobodnaevropa.org./content/most_srbija_nato/1737832.html (dostęp 29 X 2012). 
Zwolennicy włączenia kraju do struktur NATO podkreślaja że mimo ogłoszonej neutralności, Serbia zezwoliła na loty samolotów Sojuszu nad swoim terytorium, podpisane są również umowy, dotyczące operacji lądowych (przerzucanie oddziałów wojskowych). Ponadto kryzys na południu Serbii został zażegnany z pomoca wojsk NATO, co oznacza, że w istocie, także od strony prawnej, trudno mówić o neutralności kraju.

Pozostając w kręgu zagadnień militarnych, porusza się bardzo często kwestię już przeprowadzonych w armii serbskiej reform, zgodnie ze standardami NATO, będacymi z cała pewnością najlepszymi w świecie. Stąd obecna dezorientacja armii, która nie wie, w jakiej znajduje się sytuacji - czy kraj jest $\mathrm{w}$ istocie neutralny, czy dalej ma postępować według standardów natowskich. Jednak podkreśla się, że wstapieniem do Paktu Serbia nie tylko zapewniłaby sobie pokój, ale przede wszystkim jej przypadłaby wiodąca rola w systemie bezpieczeństwa na Bałkanach i w południowo-wschodniej Europie.

Przeciwnicy integracji na pierwsze miejsce, obok bombardowań z 1999 r., wysuwaja kwestię Kosowa. W tej sprawie wypowiedział się sekretarz generalny NATO, Anders Fogh Rasmussen, który stwierdził: Bardzo bym pragnat, by doszło do postępu w stosunkach pomiędzy Serbia i Unia Europejska, stad istotne znaczenie ma fakt, by Serbia spostrzegta, że potrzebne jest znalezienie konstruktywnego, politycznego rozwiqzania sprawy Kosowa. A dalej skonstatował: Zachodnie Batkany uważam za ,niezakończona pracę"17.

Kosowo stanowi równocześnie argument dla zwolenników wstapienia do Sojuszu, którzy podkreślaja, że Serbii będzie

${ }^{17}$ Rasmusen: Korak po korak do NATO-a, http://www.rts.rs/page/stories/sr/story/9/Politika/1132486/Rasmusen\%3A+Korak+po+korak+do+NATO-a.html (dostęp 29 X 2012). 
znacznie łatwiej prowadzić pertraktacje w tej sprawie, jeśli $\mathrm{z}$ racji swej neutralności nie będzie pozostawała $\mathrm{w}$ napiętych stosunkach ze swymi sasiadami. Nie można, ich zdaniem, ustosunkowywać się niechętnie wobec NATO, zważywszy, że stacjonują tam ciagle siły KFOR i EULEX. Ponadto może się zdarzyć, że siły zbrojne Republiki Kosowa znajdą się wcześniej w strukturach Paktu, co dla Serbii stworzyłoby niezbyt komfortową sytuację.

Jednak największe zastrzeżenia przed akcesja powoduje w Serbii obawa popsucia stosunków z Rosja która popiera serbskie roszczenia terytorialne w kwestii Kosowa. Ponadto rzą w Belgradzie obawia się ewentualnej reakcji Moskwy, mogącej wpłynać na zaopatrzenie kraju w surowce strategiczne. Nie wydaje się to uzasadnione, głównie z tego wzglę$\mathrm{du}$, że Rosja nie pozostaje we wrogich stosunkach z Sojuszem Północnoatlantyckim, ani z którymkolwiek krajem do niego należącym. W tym miejscu jako przykład przywoływane są stosunki z państwami wchodzącymi niegdyś do Układu Warszawskiego, a dziśs należącymi do $\mathrm{NATO}^{18}$.

$$
* * *
$$

Nie ulega wątpliwości, że jednym z najbardziej strategicznych priorytetów Serbii jest wejście do Unii Europejskiej. Czy uda się to bez członkostwa w NATO? Należy podkreślić, że wszystkie byłe państwa socjalistyczne przed przystapieniem do UE, stały się najpierw krajami sojuszniczymi Paktu. Sekretarz generalny NATO Rasmussen, pytany w kontekście niezbyt przychylnego stosunku serbskiego rządu wobec ewentualnego wstapienia do struktur NATO, odpowiedział, że catkowicie szanuje to, co w końcu będzie decyzja samych Serbów. Równocześnie podkreślił kwestię, o której Serbowie zdaja

${ }^{18}$ Zob. Programi/Most. Srbija u NATO... 
się nie pamiętać, a mianowicie to, że jeśli któryś kraj stara się o członkostwo w Unii Europejskiej, musi spełniać normy bardzo zbliżone do tych, które są wymagane w przypadku wstapienia do Sojuszu ${ }^{19}$.

Podsumowując, najprawdopodobniej przyszłość Serbii w NATO jest nieuniknioną koniecznością. Kraj ten nie będzie mógł się ciagle wzbraniać przed wpływami Zachodu. Jednak najważniejszą korzyścia, płynącą z ewentualnego członkostwa, oprócz gwarancji bezpieczeństwa, wydaje się być wzmocnienie politycznego autorytetu Serbii na arenie międzynarodowej. To zaś sprawi, że stanie się ona bardziej interesująca ekonomicznie, a otwierając się dla obcych inwestorów, przyspieszy swój rozwój gospodarczy.

${ }^{19}$ Rasmusen: Korak po... 